\title{
Polymodal emergence pattern and parasitoid composition of Asteralobia sasakii (Monzen) (Diptera: Cecidomyiidae) on Ilex crenata and I. integra (Aquifoliaceae)
}

\author{
Ken TabuChi and Hiroshi Amano* \\ Laboratory of Applied Entomology and Zoology, Faculty of Horticulture, Chiba University; Matsudo, Chiba 271-8510, Japan \\ (Received 25 September 2002; Accepted 9 June 2003)
}

\begin{abstract}
In a population of the gall midge Asteralobia sasakii, we discovered individuals that entered a prolonged diapause. To interpret the adaptive significance of this prolonged diapause, the life history of $A$. sasakii was investigated in relation to parasitoid attacks. The survey was conducted on two host plants, Ilex crenata and I. integra in central Honshu, Japan. The majority of midges were univoltine and spent only one winter as mature larvae. On I. integra, some individuals diapaused in the first stadium and spent two or more winters, so that the total emergence pattern was a polymodal pattern. The advantage of the prolonged diapause was unclear. Allochronic isolation was found between the two host-associated populations of $A$. sasakii in the field. The two populations of midges also differed in the species composition of parasitoids. Our results suggest that the two populations of $A$. sasakii belong to two distinct biological species.
\end{abstract}

Key words: Prolonged diapause; Asteralobia sasakii; Ilex; gall midge; parasitoid complex

\section{INTRODUCTION}

In many insect species, a part of the population enters a prolonged diapause and the emergence of the adults from a year cohort often extends over two or more years (Waldbauer, 1978). This phenomenon has often been observed in insect species that utilize unstable resources or that live under high predation pressure from natural enemies (Sunose, 1983a).

Some gall midges are reported to enter prolonged diapause (e.g. Barnes, 1956; Redfern, 1975; Maeda et al., 1982; Takasu and Yukawa, 1984). Two types of prolonged diapause have been described in cecidomyiid midges: first, some midges undergo prolonged diapause after the gall matures (Barnes, 1956; Barnes and Arnold, 1960; Sunose, 1978). The diapausing stages are mature larvae or pre-pupae. These midges enter a prolonged diapause in full-grown galls either on the host plant or on the ground (Sunose, 1978; Prévost, 1990). Otherwise, mature larvae escape from the gall and form a cocoon to diapause on the ground (Barnes, 1956; Barnes and Arnold, 1960). Second, other midges enter a prolonged diapause in the first or second stadia in immature galls on the host plant (Redfern, 1975; Maeda et al., 1982; Ohno and Yukawa, 1984; Takasu and Yukawa, 1984).

Generally, populations of gall-forming insects suffer selective pressures from parasitoid attacks and fluctuations in the amount of their resources (e.g. Redfern and Cameron, 1978; Prévost 1990). These threats might cause extinction of the insect populations. Thus, individuals entering prolonged diapause seem to play an important role in preventing the extinction of certain populations (Yukawa, 2000), irrespective of the underlying mechanism of its evolution. In Dasineura rachiphaga and Hasegawaia sasacola, food shortage and the associated absence of oviposition sites are considered as the major selective factors of prolonged diapause (Sunose, 1978; Prévost, 1990). By contrast, an important mortality factor in Daphnephila machilicola, Pseudasphondylia neolitseae and Taxomyia taxi is parasitoid attacks, so that diapause would provide a means of escaping from such attacks (Redfern and Cameron, 1978; Maeda et al., 1982; Takasu and Yukawa, 1984).

The gall midge Asteralobia sasakii (Monzen) is reported to be univoltine (Yukawa, 1971; Yukawa

\footnotetext{
* To whom correspondence should be addressed at: E-mail: amano@faculty.chiba-u.jp
} 
and Masuda, 1996). However, a preliminary field observation showed that an A. sasakii population consists of individuals with two- and three-year life histories. For some midges that induce galls on the leaves of evergreen trees, it is hypothesized that prolonged diapause has evolved mainly for hedging the risk of parasitoid attacks rather than for evading food shortages, which seldom occur in broad-leaved evergreen forests (Yukawa, 2000). The purpose of this study was to clarify how midges cope with parasitoid attacks by prolonged diapause. To resolve this problem, we clarified the life cycle of $A$. sasakii and the frequency of populations entering a prolonged diapause. The life histories of parasitoid wasps that parasitize the midge larvae were also investigated.

\section{MATERIALS AND METHODS}

Insects. In Japan, five Asteralobia species are known (Yukawa, 1983b; Yukawa and Masuda, 1996). The gall midge $A$. sasakii was first reported by Sasaki (1902) as a pest of Ilex crenata (Aquifoliaceae), because it prevented the growth of new shoots. This gall midge is commonly found on several Ilex trees (I. chinensis, I. crenata, I. crenata var. paludosa, I. goshiensis, I. integra, I. leucoclada and I. warburgii) throughout Japan (Monzen, 1937; Shinji, 1944; Yukawa, 1976, 1982; Yamauchi et al., 1982; Yukawa and Sunose, 1988; Yukawa and Masuda, 1996). Recently, Tokuda et al. (2002) reported midge galls on I. maximowicziana from the Southwest Islands in Japan. This species causes spherical galls on the axillary buds of shoots (Monzen, 1937; Yukawa and Masuda, 1996). Mature galls formed by $A$. sasakii are 3 to $24 \mathrm{~mm}$ in diameter, and contain 1 to 25 larvae, which individually form their own cells (K. Tabuchi and $\mathrm{H}$. Amano, personal observation).

Another species, A. soyogo (Kikuti), is also known to cause axillary bud galls on I. pedunculosa in Japan (Kikuti, 1939). Because this species cannot be easily distinguished from $A$. sasakii (Yukawa, 1971; Yukawa and Masuda, 1996), Yukawa (1971) stated that further comparative studies were needed to determine the taxonomic status of Asteralobia midges on different Ilex species.

A. sasakii has been reported to be univoltine: adults emerge from overwintering galls on shoots from late April to June. After mating, adult females oviposit into axillary buds of shoots. The galls mature by autumn, and larvae complete their growth in October. The matured larvae overwinter in the galls and then pupate in the following March (Yukawa and Masuda, 1996).

Field observations and experiments. At Matsudo Campus, Chiba University (Matsudo-city, Chiba Prefecture) in central Honshu, Japan, we investigated the life history of $A$. sasakii on two host plants, I. crenata ([Inutsuge] in Japanese) and I. integra ([Mochinoki] in Japanese) in 2000 and 2001. In Japan, these trees are often planted for hedges or for windbreaks. For example, I. crenata is planted around fruit orchards as a windbreak (Kunimoto et al., 1994).

To determine the life history of the midges and parasitoids, we chose seven trees of I. crenata (1.6-3.5 $\mathrm{m}$ high) and 29 trees of I. integra (1.5-5 m high) as census trees. We sampled five gall-bearing shoots from the census trees of two host plants weekly from June 2000 to December 2001. In the laboratory, the collected galls were measured and dissected under a binocular microscope. Larval stadia differ in body size (first stadium: 0.25$0.38 \mathrm{~mm}$; second stadium: $0.73-1.13 \mathrm{~mm}$; third stadium: $2.33-3.10 \mathrm{~mm}$; K. Tabuchi and H. Amano, unpublished data), so that we determined the stadia of the larvae in the galls based on their body sizes. In this survey, parasitoid larvae and pupae in the dissected galls were transferred to gelatin capsules and reared until adult emergence. On each sampling date, parasitoid adults that were ovipositing in the gall were also collected. Growth of galls was investigated once a month. On each sampling date from July 2001 to August 2002, we collected five galls on the census trees of $I$. crenata, and five galls of one-year type and two galls of two-year type on the census trees of I. integra. The galls were measured and dissected as described above. Galls that started to grow soon after gall formation and had second and third stadia larvae were regarded as one-year type galls, and galls that had remained immature and small and had first stadium larvae were regarded as two-year type galls.

Adult emergence was observed from mid April to early June in 2001 and 2002. In 2002, we also observed the emergence of adults that had entered prolonged diapause. In the survey, we randomly chose gall-bearing shoots on $I$. crenata and $I$. 
Table 1. Characteristics of galls in a survey of adult emergence on I. integra and I. crenata in 2001 and 2002

\begin{tabular}{|c|c|c|c|c|c|c|}
\hline Host plant & Year of observation & Year of birth & Type of life cycle & No. of galls & No. of shoots & No. of trees \\
\hline \multirow[t]{2}{*}{ I. crenata } & 2001 & 2000 & 1-year & 50 & 17 & 6 \\
\hline & 2002 & 2001 & 1-year & 51 & 29 & 6 \\
\hline \multirow[t]{3}{*}{ I. integra } & 2001 & 2000 & 1-year & 65 & 15 & 8 \\
\hline & 2002 & 2001 & 1-year & 51 & 22 & 7 \\
\hline & & 2000 & 2-year & 36 & 19 & 12 \\
\hline
\end{tabular}

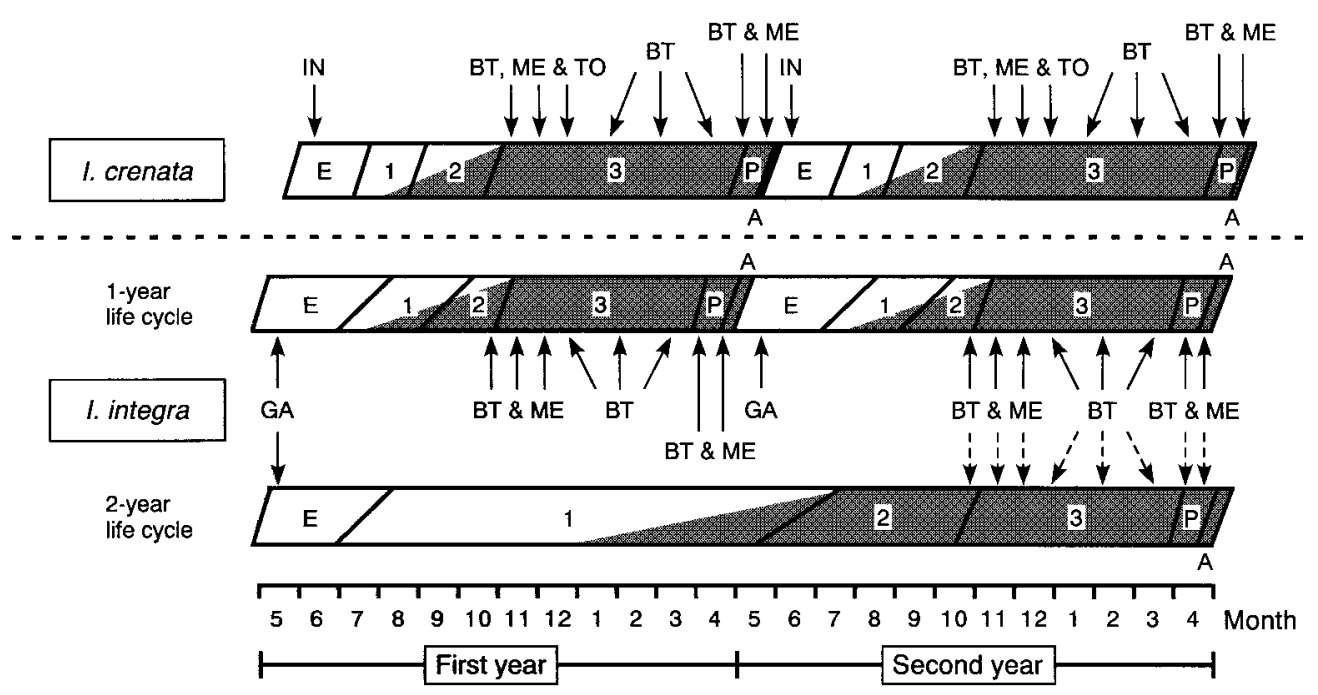

Fig. 1. Schematic representation of the one-year and two-year type life histories of A. sasakii on I. crenata and I. integra, and its developmental stages attacked by six hymenopterous parasitoids. Grayed areas indicate the maturity of the gall; arrows towards the developmental stages of the host midge indicate ovipositional attack by the parasitoids; dotted arrows indicate the attack on the two-year type host by the parasitoids. IN, Inostemma sp. [Platygastridae]; BT, Bracon tamabae [Braconidae]; ME, Mesopolobus sp. [Pteromalidae]; TO, Torymus sp. [Torymidae]; GA, Gastrancistrus sp. [Pteromalidae]. E, eggs; 1, 2 and 3, first, second and third stadium larvae; P, pupae; A, adult.

integra (Table 1), and enclosed them in nylon-mesh bags on April 20 in 2001 and on April 8 in 2002. Newly emerged adults were counted daily until the termination of adult emergence.

During the period when the galls do not grow (mid November to late March), we sampled firstand second-year old galls from one tree of each host plant species. The galls were dissected to count the numbers of diapausing and non-diapausing midge larvae inside. At the end of the above period, the percentage of individuals that had entered prolonged diapause was calculated in 2001 and 2002. In 2001, different trees were selected for investigation to avoid any influence from the 2000 survey.

\section{RESULTS}

\section{Midges with one-year type life history}

Most A. sasakii were univoltine (Fig. 1), in agreement with previous studies (Yukawa, 1971; Yukawa and Masuda, 1996). However, the $A$. sasakii population on I. crenata and that on I. integra differed in developmental phenology. Adults emerged from overwintered galls on shoots from mid April to late May (Fig. 1), but the adult emergence periods of the two populations never overlapped (Fig. 2). The last day of adult emergence on I. integra was six days earlier than the first day of adult emergence on I. crenata in 2001 and 11 days earlier than the first day of adult emergence on $I$. crenata in 2002 (Fig. 2). For I. integra, the 50\% adult emergence day was 2 May in 2001 and 22 April in 2002, while for I. crenata, the $50 \%$ adult 
- Integra population (one-year cycle)

๑ I. integra population (two-year cycle)

I. crenata population

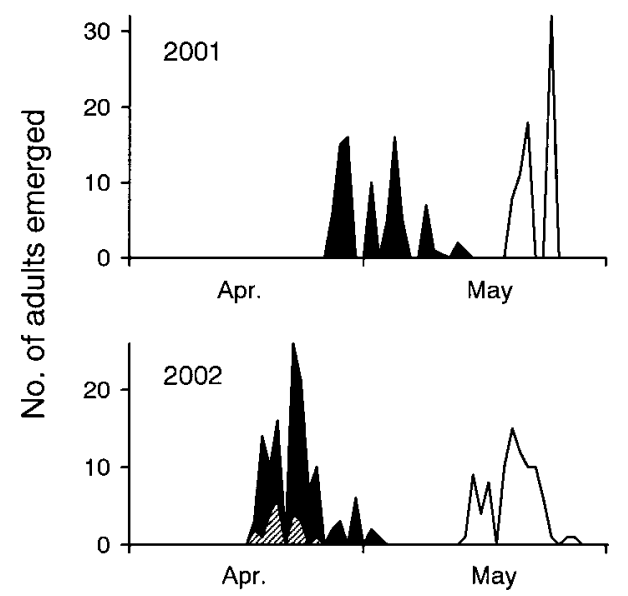

Fig. 2. Adult emergence of $A$. sasakii in 2001 and 2002. Black peaks, I. integra population (one-year cycle) $(n=84$ [male $n=43$ and female $n=41$ ] in 2001 and $n=101$ [male $n=46$ and female $n=55]$ in 2002); white peaks, I. crenata population ( $n=69$ [male $n=22$ and female $n=47$ ] in 2001 and $n=88$ [male $n=24$ and female $n=64$ ] in 2002); hatched peaks, I. integra population (two-year cycle) $(n=21$ [male $n=12$ and female $n=9$ ] in 2002).

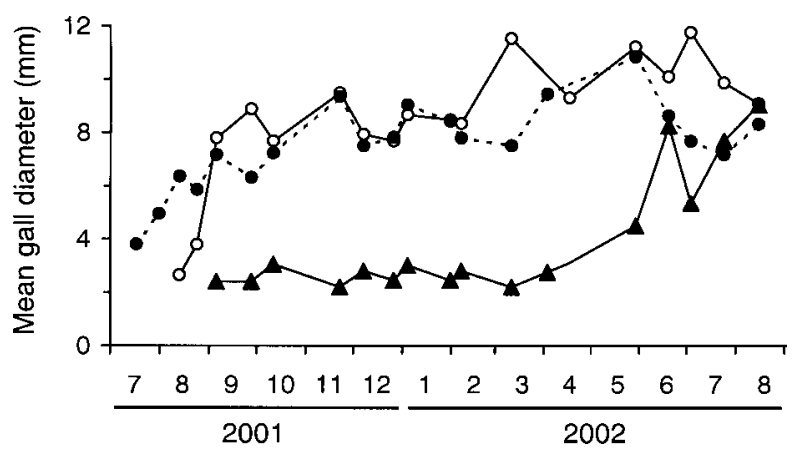

Fig. 3. Growth pattern of $A$. sasakii galls on I. crenata $(\bigcirc-\bigcirc)$ and I. integra (one-year type: $-\bullet$ - two-year type:

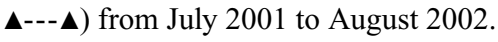

emergence day was 22 May and 20 May, respectively. The emergence period on I. integra was longer than that on I. crenata in both years (Fig. 2). Eggs of both populations hatched in June and July, when the galls started to develop (Fig. 3). The timing of larval development differed slightly between the two populations. Eggs of the A. sasakii population on I. crenata tended to hatch later but larvae matured earlier than those of the A. sasakii population on I. integra. The galls tended to develop faster on I. crenata than on I. integra (Fig. 3). Pupation occurred at the end of March in the galls on
I. integra, while it occurred from mid April to May on I. crenata (Fig. 1).

\section{Midges with two- and three-year type life his- tory}

Of a total of 1,682 larvae observed in 369 galls on I. crenata in 2000 (676 larvae in 172 galls) and 2001 (1,006 larvae in 197 galls), none had a life cycle beyond one year. On the other hand, on I. integra, many of the first stadium larvae underwent a prolonged diapause in immature galls $(21.8 \%$ in 2000 and $23.9 \%$ in 2001) (Table 2). Diapausing individuals were rarely found in galls with larvae of the one-year type life cycle on I. integra (one gall in 2000 and three galls in 2001). The percentage of galls that contained only diapausing individuals was $98.8 \%(79 / 80)$ in 2000 and $95.7 \%(66 / 69)$ in 2001 (Table 2). Like the univoltine larvae, larvae of the two-year type also form immature galls in July (Fig. 1). First stadium larvae undergoing a prolonged diapause passed the summer, autumn and winter in immature galls. These galls started to develop in the following spring (Fig. 3) and the larvae matured in the following autumn. Thus, mature larvae of the two-year type were found in autumn in galls on second-year shoots: 49 larvae in 25 galls in 2000 and 298 larvae in 126 galls in 2001 (Table 2). These larvae pupated in the same season as the current individuals of the one-year type, and adults of both populations emerged simultaneously (Fig. 2). In 2001, individuals with a three-year life cycle were found on third-year shoots of I. integra (Table 2). First stadium larvae of the three-year type were observed in the winter of the second year, and second stadium larvae appeared in June. These individuals seemed to remain in immature galls on the axillary buds of shoots until spring of the third year and develop to successive stages as the two-year type population (Fig. 1).

\section{Parasitoids}

Five species of wasps were parasitic on $A$. sasakii (Fig. 1). The species composition in the parasitoid complexes differed between the two populations of $A$. sasakii inhabiting I. crenata and I. integra.

Inostemma sp. (Platygastridae) and Torymus sp. (Torymidae) were observed only in galls on I. crenata, while Gastrancistrus sp. (Pteromalidae) was observed only in galls on I. integra. On the other 
Table 2. Examples of one-year, two-year and three-year-type life cycles of midges inhabiting I. integra and I. crenata in 2000 and 2001

\begin{tabular}{|c|c|c|c|c|c|c|c|}
\hline Host plant & Tree no. & $\begin{array}{c}\text { Year of } \\
\text { observation }\end{array}$ & $\begin{array}{l}\text { Year of } \\
\text { birth }\end{array}$ & $\begin{array}{l}\text { Type of } \\
\text { life cycle }\end{array}$ & $\begin{array}{l}\text { No. of } \\
\text { galls }\end{array}$ & $\begin{array}{l}\text { No. of } \\
\text { larvae }\end{array}$ & $\begin{array}{c}\text { Diapausing } \\
\text { rate }(\%)\end{array}$ \\
\hline \multirow[t]{2}{*}{ I. crenata } & Tree 1 & 2000 & 2000 & 1-year & 172 & 676 & 0 \\
\hline & Tree 2 & 2001 & 2001 & 1-year & 197 & 1,006 & 0 \\
\hline \multirow[t]{12}{*}{ I. integra } & \multirow[t]{6}{*}{ Tree 1} & \multirow[t]{6}{*}{2000} & 1999 & 3-year & 0 & 0 & \multirow{2}{*}{0} \\
\hline & & & 1999 & 2-year & 25 & 49 & \\
\hline & & & 2000 & 2-year & 79 & 207 & \multirow{4}{*}{21.8} \\
\hline & & & \multirow[t]{2}{*}{2000} & 2-year & 1 & 3 & \\
\hline & & & & 1-year & & 2 & \\
\hline & & & 2000 & 1 -year & 269 & 753 & \\
\hline & \multirow{6}{*}{ Tree 2} & \multirow{6}{*}{2001} & 2000 & 3-year & 12 & 18 & \multirow{2}{*}{5.7} \\
\hline & & & 2000 & 2-year & 126 & 298 & \\
\hline & & & 2001 & 2-year & 66 & 161 & \multirow{4}{*}{23.9} \\
\hline & & & \multirow{2}{*}{2001} & 2-year & 3 & 4 & \\
\hline & & & & 1-year & & 6 & \\
\hline & & & 2001 & 1-year & 194 & 518 & \\
\hline
\end{tabular}

hand, Bracon tamabae Maetô (Braconidae) and Mesopolobus sp. (Pteromalidae) were observed in galls on both I. crenata and I. integra.

Inostemma sp. and Gastrancistrus sp., which attacked host midge eggs in late spring, were possibly monophagous endoparasitoids. Inostemma sp. had a univoltine life cycle. Most Gastrancistrus sp. individuals were univoltine. However, this species also attacked the population of $A$. sasakii with a two-year life cycle, and in this case, the parasitoid also entered a prolonged diapause with the midge larvae, taking two years to complete its life cycle.

Three ectoparasitoids, B. tamabae, Mesopolobus sp. and Torymus sp. were recorded from A. sasakii larvae. B. tamabae is a multivoltine ectoparasitoid that attacks mature larvae and pupae of several gall midges (Yukawa, 1983a; Takasu and Yukawa, 1984; Maetô, 1991). In addition to A. sasakii (this report), Daphnephila machilicola, Masakimyia pustulae and Pseudasphondylia neolitseae are also known as hosts (Maetô, 1991). Yukawa (1983a) has described the life history of $B$. tamabae (referred to as Ipobracon scurra) parasitizing $P$. neolitseae. This parasitoid grew rapidly after oviposition, and attacked host midges from December to the following April. In our survey, this parasitoid attacks mainly in October and November, with oc- casional attacks from December to the next spring (Fig. 1).

Mesopolobus sp., like B. tamabae, is multivoltine. It attacked midges in at least two seasons: it attacked mature larvae in autumn and pupae in spring. Most of the adults of this parasitoid were observed in autumn and the remainder were observed in spring. From December to March, all of the parasitoids observed were in the egg or young larval stage, so it was difficult to determine whether they were Mesopolobus sp. or B. tamabae.

Torymus sp. was univoltine and attacked only mature larvae of A. sasakii on I. crenata.

\section{DISCUSSION}

Some individuals of $A$. sasakii entered prolonged diapause only on I. integra. In addition, the parasitoid fauna differed between the two midge populations inhabiting $I$. crenata and I. integra. Our study also suggested possible reproductive isolation between the midge population on I. crenata and that on I. integra, because the emergence period of adults of the two populations never overlapped. In general, the longevity of cecidomyiid midges is short and most midge adults can survive for only one or a few days (Barnes, 1956; Yukawa 
et al., 1976; Sunose, 1983b; Miller and Borden, 1984; Yukawa and Ohsaki, 1988). Our observations showed that the captive, non-breeding $A$. sasakii adults in small plastic cups lived for four or five days on average (Tabuchi and Amano, 2003). Some authors pointed out that midges which were maintained in small vials in the laboratory or which were prevented from mating usually lived longer (several days) (Miller and Borden, 1984; Isidoro et al., 1992; Pivnick and Labbé, 1992). Therefore, the life span of $A$. sasakii adults in the field is probably shorter than four days and the $A$. sasakii populations inhabiting the two host species would not interbreed in the field. Judging from the morphological differences between the two populations of A. sasakii (M. Tokuda and J. Yukawa, personal communication) and their allochronical isolation (this study), the two populations can be regarded as biologically distinct species. As mentioned above, A. soyogo also induces axillary bud galls on I. pedunculosa (Kikuti, 1939). An analysis of mtDNA sequences suggests that $A$. sasakii populations inhabiting $I$. crenata var. paludosa and $I$. maximowicziana are possibly identical with $A$. sasakii on I. crenata, and that A. sasakii populations inhabiting $I$. chinensis and I. integra seem to be identical to $A$. soyogo on I. pedunculosa (M. Tokuda and J. Yukawa, personal communication). Further studies on the life cycle and host preference of the midges in more localities are needed to clarify their taxonomic status.

The present survey revealed the occurrence of a three-year life cycle in the A. sasakii population on I. integra. This type of life cycle has been reported for the machilus leaf gall midge Daphnephila machilicola (Maeda et al., 1982). In this species, the larvae of the three-year type remain in the first stadium in the leaf blade until autumn of the third year and then develop into the next stadium (Maeda et al., 1982). Similarly, in A. sasakii the first stadium larvae of the three-year population appear to remain in immature galls on the axillary buds until the spring of the third year, at least, and then start to develop into the successive stages.

The adults of the two-year life cycle emerged synchronously with those of the one-year life cycle (Fig. 2). In other midges with a prolonged diapause stage as well, adults of different life cycles emerge at the same time (e.g. Redfern, 1975; Maeda et al., 1982; Takasu and Yukawa, 1984; Prévost 1990).
These results suggest that mating can occur between conspecific populations with different life cycles, indicating that the difference in life cycle can be regarded as an intraspecific variation. Maeda et al. (1982) states that the co-occurrence of one-year and two-year life cycles in gall midges is due to genetic variation in the progeny produced by a single female. In A. sasakii on I. integra, larvae with different life cycles were observed among different galls on the same shoots, but rarely in the same galls. In this study, therefore, observed life history variation might have been produced by either innate genetic heterogeneity of females or inter-gall variations in environmental conditions. It is unknown whether single females produce single galls in the field, or how larvae in certain galls maintain almost the same life cycle.

On I. integra, diapausing individuals of $A$. sasakii can avoid a primary attack by ectoparasitoids that target mature larvae and pupae in the first year, by taking advantage of the difference in developmental time (Fig. 1). In the season when ectoparasitoids attack, the first stadium larvae are too small to serve as food resources. In the same manner, the larvae could escape from attacks by Gastrancistrus sp. which targets midge eggs in the second year. When Gastrancistrus sp. adults emerge, the developmental stages of the one- and two-year populations of $A$. sasakii are different: the one-year population is in the egg stage, whereas the two-year population is in the first stadium (Fig. 1). However, larvae of Gastrancistrus sp. were often observed in midge larvae inhabiting two-year galls. These results suggest that this endoparasitoid enters a prolonged diapause in diapausing midge larvae in the gall. The same relationship has been reported in another endoparasitoid Gastrancistrus sp. that attacks diapausing first stadium larvae of Pseudasphondylia neolitseae (Takasu and Yukawa, 1984).

In general, diapausing populations face more difficulties in completing their life cycle than those with a one-year life cycle due to the longer time required for developing. Nevertheless, there were diapausing populations in every cohort of $A$. sasakii, and an apparent life history polymorphism was maintained. For other gall midges inhabiting evergreen trees, a prolonged diapause is postulated to have evolved to diversify the risk of parasitoid attack (Maeda et al., 1982; Takasu and Yukawa, 
1984; Yukawa, 2000). In A. sasakii inhabiting I. integra, the occurrence of prolonged diapause may represent a "bet-hedging" strategy against the attacks of natural enemies. However, the advantages of the diapausing individuals was not apparent in this study. To better understand how prolonged diapausing diversifies the risk of natural enemy attacks, additional studies are needed to compare the effects of parasitoid attacks on annual individuals and individuals undergoing prolonged diapause.

\section{ACKNOWLEDGEMENTS}

We thank Dr. K. Konishi (National Agricultural Research Center for Hokkaido Region) for helping to identify parasitoid wasps. We also thank Dr. K. Kamijo for identification of the Pteromalidae and Torymidae, Dr. K. Maetô (Laboratory of Entomology, Faculty of Agriculture, Kobe University) for identification of the Braconidae, and Dr. K. Yamagishi (Entomological Laboratory, Faculty of Agriculture, Meijo University) for identification of the Platygastridae.

\section{REFERENCES}

Barnes, H. F. (1956) Gall Midges of Economic Importance. VII. Cereal Crops. Crosby Lockwood \& Son, London. $261 \mathrm{pp}$

Barnes, H. F. and M. K. Arnold (1960) Delayed emergence of the pea midge. Plant Pathol. 9: 52-54.

Isidoro, N., I. H. Williams, M. Solinas and A. Martin (1992) Mating behavior and identification of the female sex pheromone gland in the brassica pod midge (Dasineura brassicae Winn.: Cecidomyiidae, Diptera). Boll. Ist. Entomol. "G. Grandi” Univ. Bologna 47: 27-48.

Kikuti, T. (1939) On two species of gall-midge of genus Schizomyia (Diptera, Cecidomyiidae). Annotness. Zool. Jap. 18: 237-241.

Kunimoto, Y., N. Shinkaji and H. Amano (1994) Occurrence of the citrus red mite, Panonychus citri (McGregor), on three forms of Irex crenata. Jpn. J. Appl. Entomol. Zool. 38: 71-78 (in Japanese with English summary).

Maeda, N., S. Satô and J. Yukawa (1982) Polymodal emergence pattern of the machilus leaf gall midge, Daphnephila machilicola Yukawa (Diptera, Cecidomyiidae). Kontyû 50: 44-50.

Maetô, K. (1991) Braconid parasitoids (Hymenoptera) of the gall-making Cecidomyiidae (Diptera) in Japan. Jpn. J. Entomol. 59: 295-313.

Miller, G. E. and J. H. Borden (1984) Reproductive behaviour of the Douglas-fir cone gall midge, Contarinia oregonensis (Diptera: Cecidomyiidae). Can. Entomol. 116: 607-618.

Monzen, K. (1937) On some new gall midges. Kontyû 11: 180-194 (in Japanese).

Ohno, K. and J. Yukawa (1984) Description of a new gall midge (Diptera, Cecidomyiidae) causing leaf galls on Camellia japonica L., with notes on its bionomics. Kontyû 52: 427-434.
Pivnick, K. A. and E. Labbé (1992) Emergence and calling rhythms, and mating behaviour of the orange wheat blossom midge, Sitodiplosis mosellana (Géhin) (Diptera: Cecidomyiidae). Can. Entomol. 124: 501-507.

Prévost, Y. H. (1990) Spruce cone axis midge, Dasineura rachiphaga Tripp (Diptera: Cecidomyiidae), in cones of black spruce, Picea mariana (Mill) B. S. P. Can. Entomol. 122: 441-447.

Redfern, M. (1975) The life history and morphology of the early stages of the yew gall midge Taxomyia taxi (Inchbald). J. Nat. Hist. 9: 513-533.

Redfern, M. and R. A. D. Cameron (1978) Population dynamics of the yew gall midge Taxomyia taxi (Inchbald) (Diptera: Cecidomyiidae). Ecol. Entomol. 3: 251-263.

Sasaki, C. (1902) Pests of Trees in Japan. Seibidô, Tokyo. $176 \mathrm{pp}$. (in Japanese).

Shinji, O. (1944) Galls and Gall Making Insects. Shunyôdo, Tokyo, 580 pp., pls. (in Japanese).

Sunose, T. (1978) Studies on extended diapause in Hasegawaia sasacola Monzen (Diptera, Cecidomyiidae) and its parasites. Kontŷि 46: 400-415.

Sunose, T. (1983a) Prolonged diapause in insects and its ecological significance. Kotaigun Seitai Gakkai Kaihô 37: 35-48 (in Japanese).

Sunose, T. (1983b) Redescription of Asphondylia morivorella (Naito), comb. n. (Diptera: Cecidomyiidae), with notes on its bionomics. Appl. Entomol. Zool. 18: 22-29.

Tabuchi, K. and H. Amano (2003) Host-associated differences in emergence pattern, reproductive behavior and life history of Asteralobia sasakii (Monzen) (Diptera: Cecidomyiidae) between populations on Ilex crenata and I. integra (Aquifoliaceae). Appl. Entomol. Zool. 38: 501-508.

Takasu, K. and J. Yukawa (1984) Two-year life history of the neolitsea leaf gall midge, Pseudasphondylia neolitseae Yukawa (Diptera, Cecidomyiidae). Kontyû 52: 596604.

Tokuda, M., N. Uechi and J. Yukawa (2002) Distribution of Asteralobia gall midges (Diptera: Cecidomyiidae) causing axillary bud galls on Ilex species (Aquifoliaceae) in Japan. Esakia 42: 19-31.

Waldbauer, G. P. (1978) Phenological adaptation and the Polymodal emergence pattern of insects. In Evolution of Insect Migration and Diapause (H. Dingle ed.). Springer-Verlag, New York, pp. 127-144.

Yamauchi, S., H. Ikenaga and J. Yukawa (1982) Midge galls collected from the south-west islands of Japan. Satsuma 31: 1-23 (in Japanese with English summary).

Yukawa, J. (1971) A revision of the Japanese gall midges. Mem. Fac. Agr. Kagoshima Univ. 8: 1-203.

Yukawa, J. (1976) Check list of midge galls of Japan, with descriptions of newly recorded galls I. Choripetalae. Mem. Fac. Agr. Kagoshima Univ. 12: 109-123.

Yukawa, J. (1982) New midge galls from Japan. Mem. Fac. Agr. Kagoshima Univ. 18: 85-96.

Yukawa, J. (1983a) Arthropod community centred upon the neolitsea leaf gall midge, Pseudasphondylia neolitseae Yukawa (Diptera, Cecidomyiidae) and its host plant, $\mathrm{Ne}$ olitsea sericea (Blume) Koidz. (Lauraceae). Mem. Fac. 
Agr. Kagoshima Univ. 19: 89-96.

Yukawa, J. (1983b) Redescription of three species of the genus Asteralobia (Diptera: Cecidomyiidae). Mem. Fac. Agr. Kagoshima Univ. 19: 97-108.

Yukawa, J. (2000) Synchronization of gallers with host plant phenology. Popul. Ecol. 42: 105-113.

Yukawa, J. and H. Masuda (1996) Insect and Mite Galls of Japan in Colors. Zenkoku Nôson Kyôiku Kyôkai, Tokyo. 826 pp. (in Japanese with English explanations for color plates).
Yukawa, J. and N. Ohsaki (1988) Adult behavior of the aucuba fruit midge, Asphondylia aucubae Yukawa and Ohsaki (Diptera, Cecidomyiidae). Kontŷ̂ 56: 645-652.

Yukawa, J. and T. Sunose (1988) Midge galls of Niigata Prefecture (Diptera: Cecidomyiidae). Trans. Essa Entomol. Soc. 66: 45-58 (in Japanese with English summary).

Yukawa, J., K. Takahashi and N. Ohsaki (1976) Population behavior of the neolitsea leaf gall midge, Pseudasphondylia neolitseae Yukawa (Diptera: Cecidomyiidae). Kontŷ̂ 44: 358-365. 